\title{
THE ACTUALIZATION OF TAZKIYATUN NAFS VALUES IN THE MORAL DEVELOPMENT OF STUDENTS OF THE ULUL ALBAB ISLAMIC STUDIES ORGANIZATION (KSI) UIN PADANG
}

\author{
Gusmi Ranti ${ }^{1 *}$ Jamaldi $^{2}$ \\ ${ }^{1}$ Islamic State University (UIN) Imam Bonjol Padang, West Sumatera, Indonesia, e-mail: gusmiranti123@gmail.com \\ ${ }^{2}$ Islamic State University (UIN) Imam Bonjol Padang, West Sumatera, Indonesia, e-mail:jamaldi123@gmail.com \\ *Corresponding Author

(C) 2021 by the authors. Submitted for possible open access publication under the terms and conditions of the Creative Commons
Attribution-ShareAlike 4.0 International License-(CC-BY-SA) (https://creativecommons.org/licenses/by-sa/4.0/)
DOI : http://dx.doi.org/10.30983/it.v5i2.4970
\begin{tabular}{|c|c|c|}
\hline Submission: 7 November 2021 & Revised : 30 December 2021 & Published: 31 December 2021 \\
\hline
\end{tabular}

\section{Abstract}

This study focuses on examining the actualization of the values of Taqkiyatun Nafs in the moral development of the students of the KSI Ulul Albab organization UIN Imam Bonjol. The thought of Imam Al-Ghazali and other scholars about the taqkiyatun nafs is very interesting and important to apply as a moral basis in developing the morals of the people, especially the development of the younger generation. By using descriptive qualitative research by conducting interviews with students who are active in KSI, it is concluded that the actualization of the values of tazkiyah al-nafs in building morals and religious character in instilling noble souls and having al-karimah character. then from the application of the values of tarkizyah al-nafs it also includes a strategy in the habituation of students of the KSI Ulul Albab organization in the hope of creating student discipline and changing bad morals or being therapy for bad souls into good morals. Even the application of tarkiyah al-nafs values in the form of mental therapy. Tazkiyah al-nafs in the form of mental therapy is based on the argument that the human soul can be treated. Efforts to treat mental illness must be done through science and charity. Science here serves to determine the cause and effect of a mental illness

Keywords: Value actualization, Tazkiyatun Nafs, KSI

\begin{abstract}
Abstrak
Penelitian ini mengkaji tentang aktualisai nilai-nilai Tazkiyatun Nafs dalam pembinaan akblak mahasiswa organisasi KSI Ulul Albab UIN Imam Bonjol. Pemikiran Imam Al-Ghaqali dan ulama lain tentang tazkiyatun nafs tersebut diterapkan sebagai landasan moril dalam pengembangan akblak umat teritama pembinaan generasi muda. Dengan menggunakan penelitian kualitatif deskriptif, peneliti melakukan wawancara dengan mahasiswa yang aktif dalam KSI serta mengamati kegiatan mereka. Sehingga dapat disimpulkan bahwa aktualisasi nilai-nilai tazkiyah al-nafs dilakukan melalui pembinaan akblak dan karakter religious dalam menanamkan jiwa-jiwa yang mulia dan berakhlaq al-karimah. Penerapan nilainilai tazkiyah al-nafs itu juga termasuk strategi dalam pembiasaan mahasiswa organisasi KSI Ulul Albab dengan harapan tercipta suatu kedisiplinan mahasiswa dan perubahan akblak yang buruk atau menjadi terapi bagi jiwa yang buruk menjadi akblak yang baik. Babkan penerapan nilai-nilai tazkiyah al-nafs dalam bentuk terapi jiwa. Tazkiyah al-nafs dalam bentuk terapi jiwa didasari argument bahwa jiwa manusia dapat diobati. Upaya pengobatan penyakit jiwa mesti dilakukan melalui ilmu dan amal. Ilmu disini berfungsi untuk mengetahi sebab dan akibat suatu penyakit jiwa
\end{abstract}

Kata Kunci: Aktualisasi nilai, Tarkiyatun nafs, KSI

\section{Background}

Tazkiyah al-Nafs is part of the mission of the Apostles, the target of the pious, and determines safety or accident in the sight of Allah. Tazkiyah etymologically has two meanings; namely, purification and growth. As well as meaning in terms. Zakah al-Nafs means purification (tathabhur) of the soul from all

diseases and defects, realizing (tahaqquq) various states of the owner, and making asthma' and character as akblaq (takhalluq). In the end, Tazkiyah is tathabhur, tahaqquq and takballuq. All of these have various syar'i means, the essence and syar'i results. Its impact and influence will be seen in the behavior in interacting with Allah 
and creatures, and in controlling the limbs according to Allah's commands. ${ }^{1}$

Moral development in Islam is also integrated with the implementation of the pillars of faith ${ }^{2}$. The results of Muhammad alGhazali's analysis of the five pillars of Islam have shown clearly that the pillars of Islam such as the creed, prayer, fasting, zakat and hajj contain the concept of moral development. ${ }^{3}$ Then another way that can be taken for this moral development is habituation that is carried out since childhood and takes place continuously ${ }^{4}$. In this regard, Imam Al-Ghazali said that the human personality can basically accept any formation effort through habituation. If humans get used to doing evil, then he will become a bad person. For this, AlGhazali recommends that morals be taught, namely by training the soul for noble work or behavior. if someone wants him to be generous then he must get used to doing generous work, until generosity and generosity become his ingrained character. ${ }^{5}$

In line with Imam Al-Ghazali's thoughts on the tarkiyatun nafs, these values have been actualized by the values of Tarkiyah al-Nafs in the moral development of students at the Islamic Studies Spirituality Student Activity Unit (UKM) Ulul Albab IAIN Imam Bonjol Padang. Founded on May 15, 1994 with the aim of building awareness and experience of Islamic values and strengthening ukhuwah Islamiyah. The purpose of the establishment of the Ulul Albab KSI UKM is to form students who have a monotheistic spirit, foster morals, ukhuwah (solidarity), independence and gather students in seeking

\footnotetext{
1 Said Hawa, Intisari Ibya' Ulumuddin al-Ghazali Mensucikan Jiwa, (Rabbani Press, t.t,), p. 2

${ }^{2}$ Kuntowijoyo, Paradigma Islam Interpretasi Untuk Aksi, (Bandung: Mizan, 1993)

${ }_{3}^{3}$ Abuddin Nata, Akblak Tasawuf dan Karakter Mulia (Jakarta: Rajawali Pers, 2015). p. 137

${ }^{4}$ Hasan Langgulung, Asas-Asas Pendidikan Islam (Jakarta: Pustaka Al-Husna, 1987. Cet. 2)
}

to increase scientific, intellectual and spiritual potential as well as prepare a supply of alumni who are affiliated with Islam and are ready to plunge to preach to the community ${ }^{6}$

The mission of this organization is first, to hold various activities in the context of developing student potential from various aspects of rubiyah (faith) and jasadiyah (physical) and fikriyah (intellectual). Second, providing coaching and development of skills and knowledge (Thulaby da'wah). Third, provide services to the campus community. and fourth is to do other efforts that do not conflict with the Qur'an and sunnah. By looking at the vision and goals of the KSI Ulul Albab organization, we clearly see that it is closely related to the actualization of Tazkiyah al-Nafs values in their lives. So that it can be related to the actualization of the values of Tarkiyah alNafs in the moral development of the students of KSI Ulul Albab UIN Imam Bonjol Padang. Several programs carried out by students of the Ulul Albab KSI organization above, are a process to study and deepen religious knowledge. So that many who enter the KSI Ulul Albab organization aim to improve their morals.

There are several relevant studies to support this study, including: First, Firdaus ${ }^{7}$,

\footnotetext{
${ }^{5}$ Abuddin Nata, Akblak Tasawuf dan Karakter Mulia,

${ }^{6}$ Suara Kampus, UKM KSI Ulul Albab UIN Imam Bonjol Padang, diakses pada tanggal 16 Juli 2020 jam 12.03

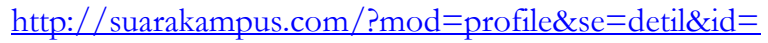
$\underline{19}$,

${ }^{7}$ Firdaus, Tazkiyah al-Nafs dalam al-Qur'an (Kajian Tafsir Tematik), Disertasi UIN Alauddin Makasar, (Makasar; 2010).
} 
Yahya $^{8}$, Masyhuri ${ }^{9}$ and Mutholingah ${ }^{10}$ which explains about tąkiyah an-nafs in the Qur'an with the various meanings contained in it. In this research, Firdaus begins his description by explaining that tarkiyah can mean growing and tabhara (purifying). While the nafs can be interpreted as al-ruh, al-syakbs, which in Indonesian the word nafs can mean lust, self, spirit, life, and also means the desire of the heart, it can be stated that tazkiyah al-nafs is a process of cleansing and purifying soul from despicable traits and actions and fill it with commendable deeds

Second, research by Ahmad Farid ${ }^{11}$, Noordin $^{12}$, Ibrahim ${ }^{13}$, Wawan ${ }^{14}$ and Sa'ari ${ }^{15}$, they explain the various methods and means in carrying out tazkiyah al-nafs carried out by Imam Ibn Rajab al-Hambali, Ibn Qayyim al-Jauziyah, Sayyid Hawa, Al-Nadwi and also al-Ghazali, where the methods and means are quoted from the books of these scholars.

Based on the studies above, generally studying the theoretical aspects of the value of tazkiyah al-nafs, only a few examine the practical aspects and the application of this value. So this study discusses the actualization of the values of Tazkiyah al-Nafs in the moral development of the students of the KSI Ulul Albab organization UIN IB Padang.

Researchers used qualitative methods by collecting data with observation techniques by

${ }^{8}$ Nur Ashidah Yahya and Fariza Md Sham, "Pendekatan Tazkiyah Al-Nafs Dalam Menangani Masalah Kemurungan," Al-Hikmab 12, no. 1 (2020): 3 18.

${ }^{9}$ Masyhuri, Masyhuri. "Prinsip-Prinsip Tazkiyah AlNafs Dalam Islam Dan Hubungannya Dengan Kesehatan Mental.” An-Nida'37, no. 2 (2012): 95-102.

${ }^{10}$ Siti Mutholingah, "Metode Penyucian Jiwa (Tazkiyah Al-Nafs) Dan Implikasinya Bagi Pendidikan Agama Islam," TaLimuna: Jurnal Pendidikan Islam 10, no. 1 (2021): 69-83.

11 Ahmad Farid, Tazkiayah an-Nufûs oleh Imam Ibnu Rajab al-Hambali, Ibnu Qayyim al-Jauriyah dan al-Ghazali, (Jakarta: Taqiya, 2012), p.12

12 Zidni Nuran Noordin and Zaizul Ab Rahman, "Perbandingan Proses Tazkiyah Al-Nafs Menurut Imam going into the field, interviews which were considered direct sources of data and holding written documentation. The data that will be studied is data about social realities that are concrete in nature.

\section{Tazkiyah al-Nafs method by Al-Ghazali}

Al-Ghazali interprets tarkiyah al-nafs as an effort to clean oneself by studying commendable types of knowledge. In the discussion about aqidah tarkizah al-nafs as an effort to know Allah (ma'rifab) and purify it (Tanqib) $^{16}$. In the discussion about taharah, tazkiyah al-nafs is cleaning the heart after cleaning the body from minor hadas and major badas. ${ }^{17}$ Thus, tarkiyah al-nafs is the process of purifying the human soul from external and internal impurities. This process is carried out in an effort to clarify the human soul by purifying or purifying the attributes of Allah first so that the human soul is filled with faith and monotheism, which is stronger and more holy than other than Allah.

Tarkiyah al-nafs also means eliminating the bad qualities that can hinder the relationship with Allah, filling it with commendable grades, and fostering and treating the soul so that human life becomes meaningful, both concerning Allah with oneself and with

Al-Ghazali Dan Ibnu Qayyim," Al-Turath Journal of AlQuran And Al-Sunnah 2, no. 1 (2017): 37-46.

${ }^{13}$ Mulyadi Ibrahim, "Rekontruksi Tazkiyah Al-Nafs Menurut Abu Hasan Al-Nadwi," At-Tafkir 13, no. 1 (2020).

14 Wawan Hernawan, "Posisi Ruh dalam Realitas Menurut Ibnu Qayim Al-Jauziyah," Syifa al-Qulub 1, no. 2 (29 Januari 2017): https://doi.org/10.15575/saq.v1i2.1433.

15 Che Zarrina Sa'ari and Sharifah Fatimah Syed Omar, "Implementasi Tasawuf Dalam Penghayatan Rukun Islam Dan Pengaruhnya Kepada Penyucian Jiwa (Tazkiyah Al-Nafs) Menurut Sa'id Hawwa," Jurnal MANU 20 (2014): 165-85.

${ }^{16}$ Yahya, Zurkani. Teologi al-Ghazali, Pendekatan Metodologi, (Yogyakarta: Pustaka Pelajar, 1996).

17 Al-Ghazali, Ibya' Ulumuddin, Jilid III, p. 52 
others. ${ }^{18}$. The rationale for the need for this method departs from the view that human morality can be improved. Strictly speaking, this moral improvement can be done through tarkiyah al-nafs. In this case, the right method is needed to change and improve morals. This method is called mujabadah (sincerity) and riyadah (spirit training). ${ }^{19}$

Mujahadah, in terms of language, comes from the word jabada, which is cognate with ijtihad, which means trying hard with complete sincerity to achieve the goal. In this case, mujahadah is meant as a struggle against the attraction of lust based on shari'a norms and reason. Example: someone who is always used to backbiting (talking about other people's horror), so his mouth feels itchy if he doesn't backbite. So the mujahadah that must be done is by holding back as much as possible not to talk about the horror of others, plus thinking that it is prohibited by religious shari'ah and in reason is also not good. ${ }^{20}$

While riyadah is self-imposed by getting used to doing good things, for example, someone who is used to being stingy, for instance, must make efforts to train themselves to always give to others or get used to donating for social purposes or worship facilities. This may feel very heavy in the initial phase, but if you do it gradually, you will get used to it and automatically lose the miserly nature ${ }^{21}$.

In that context, it can be understood that mujabadah and riyadah are tarkiyah al-nafs methods to improve morals. To purify the soul and make it shine, riyadah and mujahadah always go hand in hand. For example, when a person is accustomed to lying, the mujabadah that is done is to strive in earnest to give up lying,

18 Abdul Barro Sa'ad bin Muhammad Al-Takhsisi, Tarkiyah al-Nafs, terj. Muqimuddin Sholeh. Solo: Pustaka Mantiq, t.t..

${ }^{19}$ Solihin, Tasawnf Tematik (Bandung: Pustaka Setia, 2003). p. 125

${ }^{20} \mathrm{H}$ Taufik, "Tazkiyah Al-Nafs: Konsep Pendidikan Sufistik Dalam Upaya Membangun Akhlak," Jurnal Tadris 6, no. 2 (2013): 203-25. while the riyadah that must be accustomed is to always tell the truth and be accompanied by honesty.

Moral improvement can be made with tazkizah al-nafs through mental training and mujabadah. This assertion is based on alGhazali's reasoning that the riyadah and mujahadah has a specific purpose. The purpose in question, stated by al-Ghazali in Mizan alAmal, namely: know that the purpose of mujabadah and riyadah with good deeds is to perfect the soul, purify the soul and purify it as an activity in moral education. ${ }^{22}$

By this statement, the riyadah and mujahadah methods are educational activities and moral development. These two methods aim to improve, perfect, and purify the human soul. These two methods are also closely related to the good deeds that it must be practiced in applying these methods. In this context, it is clear that riyadah and mujahadah are tarkiyah alnafs methods to improve morals. In the effort of moral education and soul-cleansing to make it shine, riyadah and mujahadab always go hand in hand.

Al-Ghazali's view of good morals which is the implication and tarkiyah al-nafs, requires riyadah and mujahadah. These two methods are the most common methods, and when these two methods are combined, they mean selfrestraint (mujahadab) and self-training (riyadab), which is taking pains to practice doing good deeds and even becoming something fun. ${ }^{23}$

Self-training (riyadab) should be started after stopping bad bodily actions and after practicing in acts of worship. This opinion is based on al-Ghazali's belief that practice is a very important act of worship. Because the

${ }^{21}$ Al-Ghazali, Ibya' Ulumuddin, op. cit., Jilid III, h. 52

${ }^{22} \mathrm{Al}$ Ghazali, Mizan Al-A'mal, (editor: Sulaeman Dunia), Kairo: Maktabah al-Jundi, $1390 \mathrm{H}$

23 Al-Ghazali, Kimiya As-Sa'adat, dikumpulkan oleh Mustafa Abu Ala dalam Qushur Al-Awali, Kairo: Maktabah al-Jundi, $1390 \mathrm{H}$, 
purpose of the act of worship itself is to remember Allah, purify the soul, and beautify it so that in the soul there arises love for Allah and the hereafter, and love for the world can be removed. ${ }^{24}$.

As explained earlier, al-Ghazali conceptualized tarkiyah al-nafs as an attempt to treat mental illness and its causes. Mental illness can be treated here after the type of disease, and its grounds are diagnosed. Diagnosing the soul can be started from the state of a person's soul because mental illness can be observed from the symptoms of mental weakness. For example, a person will be subject to hunger, thirst, heat, cold, and suffering, his soul will be filled with fear, anxiety, worry, complaints, and so on, which in psychological terms are called psychosomatic symptoms. The emergence of this kind of disease is caused by the despicable qualities that exist in the soul ${ }^{25}$.

Therefore, in observing the symptoms above, al-Ghazali suggested that humans purify their souls by doing mujahadah. Mujahadah is a struggle to curb the soul from bad habits and the tendency to seek worldly satisfaction. Mujahadah can only weaken this urge. The application of mujahadah to treat the soul is discussed by al-Ghazali in his various works ${ }^{26}$.

Purification of the soul by using mujahadah is also very decisive because all immoral acts and all despicable traits can be realized because of the attraction of lust, so they must be fought with great struggle. In this case, according to alGhazali, efforts to prevent oneself from desire accompanied by mujahadah will save the perpetrators from evil morals. Bad morals will give birth to destruction in the hereafter, just as bad associations will give birth to disease in the

24 Al-Ghazali. Al-Madhnun bibi'an Ghairi Ablibi, terkumpul dalam "Qushur al-Awali" jilid II, editor: Muhammad Mustafa Abu al-Ala. Mesir: Maktabah alJundi. $1390 \mathrm{H}$

25 Al-Ghazali, Ibya' Ulumuddin, op. cit., Jilid III, h. 52

26 Siti Rahmatiah, "Pemikiran Tentang Jiwa (AlNafs) dalam Filsafat Islam," Sulesana: Jurnal Wawasan world. Destruction and disobedience concerning the immortality are like poison concerning the life of this world.

\section{Geneology of Islamic Studies Organisation (KSI) Ulul Albab UIN Imam Bonjol Padang}

Islamic Studies Organisation (KSI) is a student organization that focuses on religious studies and practices. This organization initially consisted of students who lived in the student dormitory of IAIN Imam Bonjol at that time, but it continues to grow and is in demand by students outside the dormitory.

To dig up information about the geneology of Organisation of Islamic Studies Ulul Albab UIN Imam Bonjol Padang, the authors conducted a search for both printed and electronic documentation. In addition, interviews with members of KSI Ulul Albab UIN Imam Bonjol Padang were also conducted.

The beginning of the formation of the Ulul Albab KSI organization began with forum associations and discussion groups. Over time there were more and more discussion forums, around 1994 an Islamic friendship forum was formed called FSII (Islamic friendship forum throughout Indonesia). This FSI IAIN IB changed to KSI Ulul Albab, based on the recommendation of the national meeting. ${ }^{27}$

As told by one of the ex-chairmen of the KSI Ulul albab organization UIN Imam Bonjol Padang named Septi, namely:

"At that time students needed a religious forum, so that they could jointly convey goodness on campus, so the Ulul Albab KSI organization was formed as a forum for students to improve themselves and

Keislaman 11, No. 2 (9 Maret 2018), Https://Doi.Org/10.24252/.V11i2.4538. p. 32

${ }^{27}$ Suara Kampus, UKM KSI Ulul Albab UIN Imam Bonjol Padang, diakses pada tanggal 16 Juli 2020 jam 12.03 wib, http:// suarakampus.com/?mod=profile\&se=detil\&id= $\underline{19}$ 
preach. Originally on the 15th of May one thousand nine hundred and ninety four." 28

Regarding the history of KSI, it used to only start with Youth Mosques and recitations conducted by Campus Students, after that there were several initiatives from several people to establish a forum, namely Baihoni who now works at the West Sumatra KPU, Mulyadi at IKADI, and Zulfahman as the Azkia school principal. Initially, KSI was named the Islamic Study Forum, after that it became an Islamic Study Group and now it has been changed to Islamic Studies Spirituality. This Ushuluddin Faculty student explained that this change was caused by various factors so that there were 3 name changes. ${ }^{29}$

The vision of KSI Ulul Albab is to form students who have the spirit of monotheism, to foster morals, brotherhood, independence and to bring together students to strive for increasing scientific, intellectual and spiritual potential and to prepare alumni who are affiliated with Islam and are ready to go into preaching in the community. In this case, students who are members of the UKM KSI Ulul Albab are actively involved in the activities that will be carried out.

Meanwhile, the mission of KSI is: First, holding various activities in the context of developing student potential from various aspects of rubiyah (faith) and Jasadiyah (physical) and fikriyah (intellectual). Second, providing coaching and development of skills and knowledge (Thulaby's da'wah). Third, provide services to the campus community. Fourth, doing other efforts that do not conflict with the Qur'an and Sunnah. Fifth, Amar Ma'ruf Nahi Munkar (ordering the good and forbidding the evil)

In the city of Padang, especially at UIN IB Padang KSI, it is called LDK (Campus

\footnotetext{
${ }^{28}$ Septi Wanda, (Ex Chairmen KSI Ulul Albab UIN Imam Bonjol Padang), Interview, \{20 April 2021\}

${ }^{29}$ Septi Wanda, (Ex Chairmen KSI Ulul Albab Uin Imam Bonjol Padang), Interview, \{20 April 2021\}.
}

Da'wah Institution) if in Indonesia it means LDK throughout Indonesia. Every campus has LDK, at UIN it is called LDK KSI Ulul Albab, Unand FKI Rabbani, then at UNP LDK UKK. Each LDK has a relationship that is compiled in a forum called the FSLDK. Each LDK in all Universities coordinates with each other to carry out joint activities or their respective activities in campus da'wah institutions. And there is also FSLDK-D (a forum for friendship between campus da'wah institutions between regions), which usually holds an activity once a year, the host for 2016 is Bung Hatta University. And there will also be an FSLDK$\mathrm{N}$ (forum of friendship for the National level campus missionary institution) in Riau ${ }^{30}$

For the management of campus Da'wah institutions, it is the administrator who has been issued a decree by the Chancellor at a university. Because the activities of this campus da'wah institution are very supportive of student activities engaged in religious activities which are included in the UKM (student activity unit).

LDK KSI is one of the Islamic movements within UIN IB Padang which is different from other Islamic movements such as the Muhammadiyah Student Association (IMM), the Islamic Student Association (HMI) etc. in the field of spirituality, so UKM KSI is equivalent to other UKM such as scouts and language.

As a student organization that forges spiritual activities, KSI's strengths were also expressed by Wela, explaining that:

I personally am a very layman towards religion, I don't come from a family that understands religion, so when I was on campus I found the KSI organization, thank God I was given guidance by God to enter KSI and emigrate through KSI. As a Muslim and a student, I am not a special department of Islamic

\footnotetext{
${ }^{30}$ Septi Wanda, (Ex Chairmen KSI Ulul Albab Uin Imam Bonjol Padang), Interview, \{20 April 2021\}
} 
religion. I want to find UKM that can strengthen my knowledge of religious knowledge and when I was at KSI I could control myself and always wanted to improve my morals and knowledge about religion. ${ }^{31}$

According to Wela KSI, as a Campus Da'wah Institution and also included in UKM, campuses have an important role in shaping the personality and quality of students to move in the academic field and be steady in religion. KSI provides a forum for fostering students to proceed in a better direction. On the other hand, what makes KSI different is in the boundaries between women and men, the boundaries are more maintained between men and women and in terms of clothing, personal morals follow what the Prophet of Muhammad Sallallaabu Alaibi Wasallam said.

Likewise with other KSI members, giving their views on the Ulul Albab KSI organization, one of which Husni said:

"The purpose of this KSI Ulul Albab organization is for goodness sake, so that students who enter KSI Ulul Albab, can become better in personality, because they are invited to maintain practice, they are also added to their knowledge, if they follow the KSI Ulul Albab series well, then these students will more formed to be a good Muslim, from keeping the words, deeds and keeping the heart good". 32

According to Husni, the purpose of the Ulul Albab KSI organization is as a process for students to become better people in terms of religion. Because in the organization he will be taught in terms of maintaining his practice, and increasing the demand for religious knowledge so that it will form a good Muslim who will guard his heart and mouth from bad things.

\footnotetext{
31, Wela, (Member of KSI Ulul Albab UIN Imam Bonjol Padang) Interview, \{27 April 2021\}.

32 Ahsanul Husni, (Member of KSI Ulul Albab UIN Imam Bonjol Padang) Interview, \{25 April 2021\}
}

Then the contribution of the Ulul Albab KSI organization on the UIN Imam Bonjol campus was also expressed by one of the KSI members, Puja said:

"KSI Ulul Albab is one of the organizations that can be used as an example for the UIN Imam Bonjol campus, an example of behavior, speech, in terms of clothing, serious cadres at KSI Ulul Albab, it will depict good attitudes, words and clothes in accordance with Islamic teachings",33

Interaction within the KSI Ulul Albab organization with fellow students is maintained, that it is not permissible for men and women to ikhtilat in accordance with religious prohibitions. This is maintained by the students of the KSI Ulul Albab organization, by limiting the association between brothers and sisters. And its members are guarded in interactions, such as communicating, acting, in doing good deeds, the point is to make us better. ${ }^{34}$

\section{Application of the Values of Tazkiyah Al- Nafs Student Organization (KSI) Ulul Albab UIN Imam Bonjol Padang}

Application of Tazkiyah Al-Nafs Values as Moral Development for KSI Ulul Albab Students at UIN Imam Bonjol Padang

Moral development is the first focus of attention in Islam. This can be seen from one of the apostolic missions of the Prophet Muhammad SAW. The main thing is to perfect noble character. Such Islamic attention to moral development can also be seen from Islam's attention to mental development which must take precedence over physical development, because from this good soul good deeds will be born which in the next stage will make it easier to produce goodness and

\footnotetext{
33 Puja Pramudia Ningsih, (Member of KSI Ulul Albab Uin Imam Bonjol Padang), Interview, \{25 April $2021\}$

34 Ahsanul Husni, (Member of KSI Ulul Albab UIN Imam Bonjol Padang) Interview, \{25 April 2021\}
} 
happiness for all. human life, physically and mentally. ${ }^{35}$

The scope of Islamic morality is the same as the scope of Islamic teaching itself, especially with regard to the pattern of relationships. This Islamic morality covers various aspects, starting from morals towards Allah, to morals towards fellow creatures, both humans, animals, and plants. Morals towards God can be interpreted as attitudes or actions that should be carried out by humans as creatures, to God as creator. These attitudes or actions have the characteristics of moral actions as mentioned above.

The morality of all human beings, there are many details that are put forward by the Qur'an relating to the treatment of fellow human beings ${ }^{36}$. Instructions regarding this matter are not only in the form of a prohibition on doing negative things such as killing, injuring the body, or taking property without a valid reason, but also in hurting the heart by telling someone's disgrace behind them, even if the disgrace is right or wrong, even while giving material to those who are hurting. ${ }^{37}$

The scope of Islamic morality is the same as the scope of Islamic teaching itself, especially with regard to the pattern of relationships. This Islamic morality covers various aspects, starting from morals towards Allah, to morals towards fellow creatures, both humans, animals, and plants. Morals towards God can be interpreted as attitudes or actions that should be carried out by humans as creatures, to God as creator. These attitudes or actions have the characteristics of moral actions as mentioned above.

The morality of all human beings, there are many details that are put forward by the

35 Abuddin Nata, Akblak Tasawuf dan Karakter Mulia, h. 136

36 Arfandi, Zainurohmad, "Konsep Tazkiyatun Nafs Menurut Al-Ghazali dalam Pendidikan Akhlak" (Skripsi Sarjana, IAIN Kediri, 2020), http://etheses.iainkediri.ac.id/2026/. h. 10
Qur'an relating to the treatment of fellow human beings. Instructions regarding this matter are not only in the form of a prohibition on doing negative things such as killing, injuring the body, or taking property without a valid reason, but also in hurting the heart by telling someone's disgrace behind them, even if the disgrace is right or wrong, even while giving material to those who are hurting. ${ }^{38}$

Halaqah is also known as usrah, mentoring, ta'lim. Usually they are formed because of their own awareness to study and practice Islam together. This awareness arises after they touch and receive da'wah from people who have followed halaqah. Halaqah as a tarbiyah movement began with the establishment of the Muslim Brotherhood congregation in $1928 \mathrm{AD}$ in Egypt. The movement was initiated by Hasan Al-Bana that the concept of preaching the Muslim Brotherhood is by the tarbiyah method which they define, namely the ideal way of interacting with human nature, either directly or indirectly. Then they study Islam with a certain curriculum.

Likewise, Redho explained that the function of Liqo' or halaqab is very influential on the development of a person's moral personality or soul.

"Liqo is one of our supervisors and reminders. So in liqo, the content is to remind each other in goodness. Then there we are also given motivational motivation so that we can achieve the values of tarkiyah al-nafs in this moral development. If there are certain problems or problems, we will discuss them together. Precisely liqo' is a means

\footnotetext{
37 Abuddin Nata, Akblak Tasawnf dan Karakter Mulia, 128

${ }^{38}$ Septi Wanda, (Ex Chairmen KSI Ulul Albab Uin Imam Bonjol Padang), Interview, \{20 April 2021\}.
} 
to strengthen bonds and increase our enthusiasm in studying." 39

Similar to what Febi said, Liqo is one of our supervisors and reminders. So in liqo' it contains reminding each other in goodness. Then here we are also given the motivations to be consistent with the hijrah. If there are certain problems or problems, we will discuss them together. Precisely liqo' is a means to strengthen bonds and increase our enthusiasm in studying. ${ }^{40}$

Halaqab functions to form students with a comprehensive Islamic personality. Halaqah plays a role for students to form an Islamic personality. The development of the quality and quantity of halaqah in the congregation will significantly affect the level of solidarity and productivity of Muslims. Therefore, halaqah functions as an effective cadre forum for the sustainability of Islamic organizations (zati). Halaqab does not only contain material reviews, but in halaqah there are ukhuwah who work together to improve themselves. It can be concluded that halaqah functions as a means to shape Islamic student morals in accordance with applicable norms in religion, environment and society. This was confirmed by Muhammad andra, a member of the cadre field.

"Liqo' or Halaqah for me is very important, because here we are not only taught about the religion but also our adab, whether it's our adab to the group builder, our adab to the fostered, our adab to others, our adab to the Creator, our $a d a b$ to others. when reading the Koran and others, which today have been abandoned by many children today". ${ }^{41}$

Based on the explanation about halaqah above, it can be concluded that the level of individual sincerity in carrying out halaqab activities repeatedly and more than once with

39 Redho Okkasia, (Member of KSI Ulul Albab UIN Imam Bonjol Padang) Interview, \{25 April 2021\}

${ }^{40}$ Febi Saputra Almariat, (Member of KSI Ulul Albab UIN Imam Bonjol Padang) Interview, \{27 April $2021\}$ an increasing frequency which contains elements of motivation, enthusiasm or enthusiasm in achieving the desired results in the method. acquire knowledge which then results in changes in the knowledge, behavior, and abilities of the balaqah participants.

Second, through coaching at the Wisma. Wisma is a residence for cadres facilitated by KSI. Aryogo, the head of cadre, explained that coaching at the guesthouse is very influential in the values of tarkiyah al-nafs in moral development..

"At the guesthouse, the form of coaching is how we are brothers and improve our practice. For men, it is obligatory to pray five times in congregation unless there is a syar'i excuse that makes the prayer unable to be performed in congregation. Then the recitations and even sunnah prayers such as Qiyamul lail, or dhuba are discussed (demanded). there is also a day for the tabfidz, program with the target memorized, and also for sermon training by rotating each person to give the sermon, later corrected if something goes wrong. Training the spirit of togetherness and social life, for example, can be seen from the fee system for the needs of the Wisma KSI. From there the system helps each other and closes to cover the shortcomings of his brother. If his brother is lacking for now, then he covers it, and if he is lacking he is also covered by his other brothers. That's without knowing who is lacking and so on because there is a chairman and his staff who hold this and that arrangement at the guesthouse". ${ }^{42}$

Husni also explained that KSI Ulul Albab cadres who live in the guesthouse receive religious values, there are several coachings that are carried out to increase religious understanding in terms of tazkiyah al-nafs values

${ }^{41}$ Muhammad Andra, (Member of KSI Ulul Albab UIN Imam Bonjol Padang) Interview, \{25 April 2021\}

42 Aryogo, (Member of KSI Ulul Albab UIN Imam Bonjol Padang), Interview, \{28 April 2021\} 
for students living in the guesthouse. ${ }^{43}$ It was also conveyed by Febi that coaching while at the Wisma can train someone's Yaumi Practice. Starting from an agenda such as: Fajr prayer is mandatory in congregation at the nearest mosque/mushala. After dawn you can't sleep because there is a dawn agenda every day except Sunday morning. Starting from Monday to Saturday (almasurat, sirah nabawiyah, tahsin, tahfir, sermon simulation, and evaluation of the homestead) while Sundays are joint sports.

Hasanah 'izzati said that students who live in the guesthouse must follow the rules that have been agreed upon by the DPW (Wisma Trustees) unless there are those who are unable to participate in the activities at the guesthouse 44

With the rules that exist in the guesthouse, over time the students who live in the guesthouse will get used to doing the activities in the guesthouse as well as students who are unable to implement the rules of the guesthouse so they prefer to leave the guesthouse.

The forms of values that are instilled in the guesthouse, both in the women's home and the men's house, are togetherness, cohesiveness, discipline, care and independence, so that students who stay in the homestead and have received learning and coaching at the homestead include their moral development in the homestead. tarkiyah al-nafs values.

This was said by Ela that there are advantages for students living in the guesthouse because I feel for myself that the formation of togetherness increases understanding of religion, both matters of worship, aqidah and morals. The religious understanding taught in KSI is to follow the Sunnah of the Prophet

${ }^{43}$ Ahsanul Husni, (Member of KSI Ulul Albab UIN Imam Bonjol Padang) Interview, \{28 April 2021\}

44 Hasanah Izzaty, (Member of KSI Ulul Albab UIN Imam Bonjol Padang) Interview, \{25 April 2021\}
According to the explanation above, the response from students of Islamic studies spiritual organizations in the application of tazkiyah al-nafs as expressed by Septi is how to form good morals by doing repentance, remembrance, worship, following the example of Rasulullah and istiqamah, in addition to these four, cadres KSI Ulul Albab both remind each other to do good, if something is wrong, they reprimand each other. The effort to improve good morals is to continue to carry out the method above. ${ }^{45}$ Then it's the same with Romi forming good morals by deepening religious knowledge, attending recitations, attending seminars or webinars with the topic of forming good morals, making friends with pious people, reading the Qur'an and its contents, leaving what is forbidden. by Allah and obey Allah's commands. ${ }^{46}$

According to the explanation above, the response from students of Islamic studies spiritual organizations in the application of tarkiyah al-nafs as expressed by Septi is how to form good morals by doing repentance, remembrance, worship, following the example of Rasulullah and istiqamah, in addition to these four, cadres KSI Ulul Albab both remind each other to do good, if something is wrong, they reprimand each other. The effort to improve good morals is to continue to carry out the method aboveThe method or method in implementing and fostering morals was also expressed by Yanti, namely by participating in every series of KSI activities, especially in maintaining good worship to Allah swt, and maintaining relationships with others. So that our morals can be controlled properly. by carrying out various activities or Islamic studies and various regulations at KSI that foster the morals of its cadres.

45 Septi Wanda, (Ex Ketua KSI Ulul Albab UIN Imam Bonjol Padang), Interview, \{20 April 2021\}.

${ }^{46}$ Romi Riski, (Anggota KSI Ulul Albab Uin Imam Bonjol Padang) Interview, \{28 April 2021\}. 
The application of the values of tazkiyah al-nafs as moral development according to Puja is As an ordinary human being, so as KSI Ulul Albab, both try to improve themselves and invite each other to improve themselves in implementing purification of the heart. One way is to find and get along in a good environment. Because how we are also depends on who our friends are. And we must control ourselves from doing despicable things, learn from various experiences and knowledge gained about good morals. ${ }^{47}$

\section{Application of Tazkiyah al-Nafs V alues in the Form of Mental Therapy}

Psychologists try to give some tips for treating the heart, including loving and appreciating all things, everyone and yourself. Believing that he has the ability, always grateful for all the gifts received, always happy, because a healthy soul can create a healthy body too, and understand that in this world there is no disease that cannot be cured ${ }^{48}$. Meanwhile in Islamic literature, there are also many known tips for treating the heart that are more promising, among which are the ones we are familiar with, namely: firstly understanding God's message to hear correctly, secondly making friends with good people, thirdly fasting, fourthly remembering Allah. ${ }^{49}$

The form of mental therapy here can be done by someone after first diagnosing the type of disease and its causes. The problem of mental therapy is based on al-Ghazali's argument that the soul can be treated as the body can be treated. God's prophets are doctors of the soul. They guide people to the path of victory by first taking the path of

47 Puja Pramudia Ningsih, (Anggota KSI Ulul Albab Uin Imam Bonjol Padang) Interview, \{28 April $2021\}$.

48 Anri Saputra, Mela Rospita, and Vivik Shofiah, "Qalbu Dalam Kajian Psikologi Islam," Al-Fikra: Jurnal Ilmiah Keislaman 18, no. 1 (2019): 37-51

49 Amin Syukur, Menata Hati Agar Disayang Allah, (Jakarta: Penerbit Erlangga, 2013), h. 8 purification of the heart or soul. So in doing obedience it is a medicine, while disobedience is a poison that affects the heart.

So here students of the KSI Ulul Albab organization in the application of tazkiyah al-nafs values as mental therapy as conveyed by Septi:

"First of all, we must straighten our good intentions in doing something, then repentance is the main way to heal our souls from bad things so that a pure soul can be formed. And then we always dhikr to Allah SWT, that we are only human, of course we have to practice a lot of remembrance of Allah to make our hearts better. Coupled with increasing the blessings of the prophet". ${ }^{50}$

Likewise, what Izzaty explained how to clean the soul from mental illness is to repent to Allah, remember Allah, always be patient in all things, accept the decisions that have been made by Allah, always listen to good advice, such as following religious teachings. And forms of therapy in treating bad mental illness, reading a lot of the Qur'an, performing prayers on time both obligatory and sunnah, remembrance of Allah, and self-reflection. ${ }^{51}$

Likewise, Husni said that forms of soul therapy to cleanse the soul are diligent worship, draw closer to Allah, learn to forgive, not get hurt easily, learn to think positively, and correct bad behavior. Then by multiplying remembering the breaker of the delicacy of life, namely death, so that oneself can stay away from all bad deeds. ${ }^{52}$

Then what causes a person's soul to be bad according to students of the KSI Ulul Albab organization is as conveyed by Septi is a lack of knowledge, lack of a good environment, making friends with friends who like to do bad

50 Septi Wanda, (Ex Ketua KSI Ulul Albab Uin Imam Bonjol Padang), Interview, \{25 April 2021\}.

${ }^{51}$ Hasanah Izzaty, (Anggota KSI Ulul Albab UIN Imam Bonjol Padang) Interview, \{25 April 2021$\}$

52 Ahsanul Husni, (Anggota KSI Ulul Albab UIN Imam Bonjol Padang) Interview, \{28 April 2021\} 
things, not wanting to practice the contents of the Koran and Sunnah. And what Husni also conveys is that worship is lacking, far from God, has a rough attitude, is hard-hearted, impatient, hates a lot, thinks negatively, and if a person's soul lacks faith, it causes jealousy, envy and so on. ${ }^{53}$

The application of the values of tarkiyah al-nafs in the therapy of bad souls is as explained by Septi, namely that the values mentioned above are understood first, so that they can only be applied in everyday life. Keep trying, praying, and putting your trust in Allah so that it is easy to become a human being with a clean heart. Then also expressed by Husni by getting used to the commendable traits in everyday life, it will get rid of the despicable traits from ourselves. Then the bad soul will slowly be treated with it. Then added by Yanti by deepening religious knowledge, reflecting on the mistakes that have been made, reading the Koran.

\section{Conclusion}

Based on the research that has been carried out, it can be concluded that as follows: First, the application of the values of tazkiyah alnafs in the moral development of the students of the KSI Ulul Albab organization is combined with the following materials: first, morals towards God, this is one of the main points of moral development carried out by KSI Ulul Albab students, then what is done by KSI Ulul Albab students, namely, studying and holding recitations about studying monotheism which means believing, seeing, and treating God as the only almighty one. Second, morals towards humans, here the application of students of the KSI Ulul Albab organization in morals towards fellow humans is to always study the characteristics of patience, honesty, qana'ah, and tawadhu' and so on. Then the most important thing is to apply these qualities so

53 Septi Wanda, (Ex Ketua KSI Ulul Albab UIN Imam Bonjol Padang) Interview, \{25 April 2021\}. that the values of tarkiyah al-nafs will be formed in humans. And thirdly, morals towards other God's creatures, here are ordered to always take care of nature and must love each other what is in this nature.

Second, the application of the values of tarkiyah al-nafs in mental therapy for the students of the KSI Ulul Albab organization is: First of all, we must straighten good intentions in doing something, be diligent in worshiping, draw closer to Allah, learn to forgive, not easily get hurt, learn positive thinking, correct bad behavior. Then by multiplying remembering the breaker of the pleasures of life, namely death, so that oneself can stay away from all bad deeds. Then repenting becomes the main way to heal our souls from bad things so that the sanctity of the soul can be formed.

\section{References}

Al-Ghazali, Ibya' Ulumuddin, op. cit., Jilid III, Kairo: Maktabah al-Jundi, $1390 \mathrm{H}$

------, Al-Madhnun bibi'an Ghairi Ablibi, terkumpul dalam "Qushur al-Awali" jilid II, editor: Muhammad Mustafa Abu alAla. Mesir: Maktabah al-Jundi. 1390 H.

------, Kimiya As-Sa'adat, dikumpulkean oleb Mustafa Abu Ala dalam Qushur Al-Awali, Kairo: Maktabah al-Jundi, 1390 H,

, Miran Al-A'mal, (editor: Sulaeman Dunia), Kairo: Maktabah al-Jundi, 1390 $\mathrm{H}$,

Al-Takhsisi, Abdul Barro Sa'ad bin Muhammad Tazkizah al-Nafs, terj. Muqimuddin Sholeh. Solo: Pustaka Mantiq, t.t..

Farid, Ahmad, Tazkiayah an-Nufûs oleh Imam Ibnu Rajab al-Hambali, Ibnu Qayyim alJauriyah dan al-Gharali. Jakarta: Taqiya, 2012.

Firdaus, Tazkiyah al-Nafs dalam al-Qur'an (Kajian Tafsir Tematik), Disertasi UIN Alauddin Makasar, Makasar; 2010. 
Hawa, Said, Intisari Ihya' Ulumuddin al-Ghazali Mensucikan Jiwa. Jakarta: Rabbani Press, t.t,

Hernawan, Wawan, "Posisi Ruh dalam Realitas Menurut Ibnu Qayim Al-Jauziyah," Syifa al-Qulub 1, no. 2 (29 Januari 2017): 182 94 ,

https://doi.org/10.15575/saq.v1i2.1433

. diakses 22 Februari 2021, pukul 11.00 wib.

Ibrahim, Mulyadi. "Rekontruksi Tazkiyah AlNafs Menurut Abu Hasan Al-Nadwi." At-Tafkir 13, no. 1 (2020).

Kuntowijoyo, Paradigma Islam Interpretasi Untuk Aksi, Bandung: Mizan, 1993.

Langgulung Hasan, Asas-Asas Pendidikan Islam Jakarta: Pustaka Al-Husna, 1987. Cet. 2

Masyhuri, Masyhuri. "Prinsip-Prinsip Tazkiyah Al-Nafs Dalam Islam Dan Hubungannya Dengan Kesehatan Mental." An-Nida' 37, no. 2 (2012): 95-102.

Mubarok, Achmad, Akblak Mulia Sebagai Konsep Pembangunan Karakter, Jakarta: GMPAC, 2009 , cet I,

Mutholingah, Siti, "Metode Penyucian Jiwa (Tazkiyah Al-Nafs) Dan Implikasinya Bagi Pendidikan Agama Islam," TaLimuna: Jurnal Pendidikan Islam 10, no. 1 (2021): 69-83.

Nata, Abuddin, Akblak Tasawnf dan Karakter Mulia. Jakarta: Rajawali Pers, 2015.

Noordin, Zidni Nuran, and Zaizul Ab Rahman. "Perbandingan Proses Tazkiyah Al-Nafs Menurut Imam Al-Ghazali Dan Ibnu Qayyim." Al-Turath Journal of Al-Quran And Al-Sunnah 2, no. 1 (2017): 37-46.

Rahmatiah, Sitti, "Pemikiran Tentang Jiwa (AlNafs) dalam Filsafat Islam," Sulesana: Jurnal Wawasan Keislaman 11, No. 2 (9 Maret 2018), Https://Doi.Org/10.24252/.V11i2.453 8. h. 32

Sa'ari, Che Zarrina, and Sharifah Fatimah Syed Omar. "Implementasi Tasawuf Dalam Penghayatan Rukun Islam Dan Pengaruhnya Kepada Penyucian Jiwa
(Tazkiyah Al-Nafs) Menurut Sa'id Hawwa." Jurnal MANU 20 (2014): 16585

Saputra, Anri, Mela Rospita, and Vivik Shofiah. "Qalbu Dalam Kajian Psikologi Islam." Al-Fikra: Jumal Ilmiab Keislaman 18, no. 1 (2019): 37-51.

Suara Kampus, UKM KSI Ulul Albab UIN Imam Bonjol Padang, diakses pada tanggal 16 Juli 2020 jam 12.03 wib, http://suarakampus.com/?mod=profile \&se $=$ detil\&id $=19$,

Syukur, Amin Menata Hati Agar Disayang Allah, Jakarta: Penerbit Erlangga, 2013

Solihin, Tasawuf Tematik (Bandung: Pustaka Setia, 2003).

Taufik, H, "Tazkiyah Al-Nafs: Konsep Pendidikan Sufistik Dalam Upaya Membangun Akhlak," Jurnal Tadris 6, no. 2 (2013): 203-25

Yahya, Nur Ashidah, and Fariza Md Sham. "Pendekatan Tazkiyah Al-Nafs Dalam Menangani Masalah Kemurungan." AlHikmah 12, no. 1 (2020): 3-18.

Yahya, Zurkani. Teologi al-Gharali, Pendekatan Metodologi, Yogyakarta: Pustaka Pelajar, 1996.

Zainurohmad, Arfandi. "Konsep Tazkiyatun Nafs Menurut Al-Ghazali dalam Pendidikan Akhlak" (Skripsi Sarjana, IAIN Kediri, 2020), http://etheses.iainkediri.ac.id/2026/. h. 10

\section{Interviews}

Septi Wanda, (Ex Chairmen KSI Ulul Albab UIN Imam Bonjol Padang), Interview, \{20 April 2021\}.

Redho Okkasia, (Member of KSI Ulul Albab UIN Imam Bonjol Padang) Interview, \{25 April 2021\}

Febi Saputra Almariat, (Member of KSI Ulul Albab UIN Imam Bonjol Padang) Interview, \{27 April 2021\} 
Muhammad Andra, (Member of KSI Ulul Albab UIN Imam Bonjol Padang) Interview, \{25 April 2021\}

Aryogo, (Member of KSI Ulul Albab UIN Imam Bonjol Padang), Interview, $\{28$ April 2021\}

Ahsanul Husni, (Member of KSI Ulul Albab UIN Imam Bonjol Padang) Interview, \{28 April 2021\}
Hasanah Izzaty, (Member of KSI Ulul Albab UIN Imam Bonjol Padang) Interview, \{25 April 2021\}

Romi Riski, (Member of KSI Ulul Albab Uin Imam Bonjol Padang) Interview, $\{28$ April 2021\}.

Puja Pramudia Ningsih, (Member of KSI Ulul Albab Uin Imam Bonjol Padang) Interview, \{28 April 2021\} 